Article

\title{
Unidirectional Rubber-Toughened Green Composites Based on PHBV
}

\author{
Zain Zaidi * ${ }^{(1)}$ and Alan Crosky
}

School of Materials Science and Engineering, University of New South Wales, Sydney, NSW 2052, Australia; a.crosky@unsw.edu.au

* Correspondence: s.z.zaidi@student.unsw.edu.au

Received: 5 April 2019; Accepted: 18 April 2019; Published: 23 April 2019

\begin{abstract}
The large-scale entry of bio-based polymers, such as poly(hydroxybutyrate-co-valerate) (PHBV), in applications commonly occupied by petroleum-based plastics is heavily limited by their poorer mechanical properties, thus, hindering efforts to reduce harmful plastic waste. Prior work to improve these properties has involved short natural fibre reinforcements, which do not produce substantial improvements. In this work, PHBV was simultaneously reinforced with unidirectional flax and toughened with poly(butylene adipate-co-terephthalate) (PBAT) or epoxidized natural rubber (ENR) to produce well-rounded composites. Toughened unidirectional composites were prepared by cryogenic grinding, powder layup and compression moulding. Unidirectional flax addition resulted in 4-fold increases in tensile properties, 3-fold increases in flexural properties and 20-fold increases in impact properties, whilst producing minimal change in the thermal properties. PBAT and ENR phases appeared well bonded to the PHBV within the composite. The addition of PBAT did not cause any significant changes in thermal or mechanical properties. The addition of ENR, however, reduced the tensile modulus and the flexural properties but produced a significant increase in impact strength, attributed to the coarse particle size of ENR. Unidirectional flax reinforcement of PHBV widens the scope of application of PHBV considerably where mechanical properties are of concern, while ENR has significant potential as a bio-based toughening agent for biocomposites.
\end{abstract}

Keywords: PHBV; natural fibre; unidirectional; natural rubber; composite; flax; PBAT; toughening agent

\section{Introduction}

The harmful impact of disposed plastics on the environment has become of increasing concern and this has led to the development of environmentally benign 'green' polymers [1]. Although biodegradability can provide a commercial advantage, mechanical performance is still paramount for fulfilling the load carrying requirements in engineering applications and biopolymers are yet to compete with synthetic polymers in this area. The mechanical performance of "green" plastics can, however, be improved through fibre reinforcement. Natural plant fibres are attractive as the reinforcement since they are renewable and biodegradable. Incorporation of these fibres into biopolymers can then provide a fully 'green composite.' One area of waste disposal which has become of particular concern in recent years is electronic waste, often referred to as e-waste [2] In the e-waste stream, the casings of items such as mobile phones, computers and printers are of particular interest since these items have only short lives but are made from materials which degrade only slowly. This is an area that could benefit considerably from the use of green materials.

The naturally occurring bacterial polyester, poly(hydroxybutyrate-co-valerate) (PHBV), is a green polymer with a hydrolysable carbon backbone, which allows it to be degraded by bacteria and enzymes and thus limit landfill saturation [3]. PHBV has been reinforced by a variety of types of 
natural fibres-pineapple [4], abaca [5-7], hemp [8-10], regenerated cellulose [6,11,12], kenaf [13-16], nanofibrillated cellulose [17], cellulose pulp [18,19], bamboo [20], jute [5,6], coir [21], peach palm particles [22], cellulose nanocrystals [23,24], bacterial cellulose [25], miscanthus [26-28], switchgrass [29], curaua [30], flax [5,6], agricultural residues [31-33] and wood [34-36]. The majority of the work to date has involved short fibres, particulates and nanofibers, with very little work having been conducted on continuous long natural fibres.

There are two major studies where PHBV has been reinforced by continuous long natural fibres. Luo et al. [4] prepared PHBV (3 mol.\% HV)/UD pineapple leaf fibre composites, containing 0-28 vol.\% fibre, using the film stacking/hot pressing route and reported at least 3-fold increases in tensile modulus and strength at $28 \mathrm{vol} . \%$. Bourban et al. [12] prepared PHBV ( 3 mol.\% HV)/regenerated cellulose fibre composites with 9.9 and $26.5 \mathrm{vol} \%$ fibre by filament winding and hot pressing. The authors reported at least 10 -fold increases in tensile modulus and strength at $26.5 \mathrm{vol} . \%$. In comparison, most short-fibre additions to PHBV have resulted in increases in mechanical properties of a maximum of 2 -fold, at volume fractions of $30 \%$. Unfortunately, the large increases due to continuous fibres were accompanied by up to $85 \%$ reductions in elongation to break, indicating a heavily embrittling effect of the fibres.

Toughening agents can be added to composites to counter this embrittling effect. There are numerous studies where polybutylene adipate-co-terephthalate (PBAT) and epoxidized natural rubber (ENR) have been added as toughening agents to PHBV/natural fibre composites but these have all been short-fibre reinforced composites $[21,26-29,37,38]$. There are no studies where both unidirectional fibres and toughening agents have been added to PHBV to produce a well-rounded high performing green composite. In this work, PHBV was simultaneously reinforced with unidirectional flax and toughened with PBAT or ENR50. The mechanical, thermal and morphological properties of the resulting composites are reported.

\section{Materials and Methods}

PHBV (ENMAT ${ }^{\circledR}$ Y1000) was obtained from Tianan Biologic Material Co, China. This commercial grade of PHBV contains $3 \mathrm{~mol} . \% \mathrm{HV}$ [17], has a melt flow index (MFI) of $2.5 \mathrm{~g} / 10 \mathrm{~min}$ at $170{ }^{\circ} \mathrm{C}[10]$ and a density of $1.25 \mathrm{~g} / \mathrm{cm}^{2}$ [34]. PBAT (Ecoflex ${ }^{\circledR} \mathrm{C} 1200 \mathrm{~F}$ ) was obtained from BASF, Germany. This commercial grade of PBAT has an MFI of $3.5 \mathrm{~g} / 10 \mathrm{~min}$ and a density of $1.26 \mathrm{~g} / \mathrm{cm}^{3}$ [39]. Epoxidized natural rubber with 50\% epoxidation (ENR50) was used here and was obtained under the trade name Epoxyrene-50 ${ }^{\circledR}$ from Industrial Organics, Australia. It has a density of $1.02 \mathrm{~g} / \mathrm{cm}^{2}$ [40]. Quasi-unidirectional flax (trade name FlaxPly ${ }^{\circledR}$ UD 180) was obtained from LINEO, Belgium. An epoxy-based sizing that constituted $16 \mathrm{wt} . \%$ of the fabric was used on the fabric to improve resin impregnation properties. The fabric consisted of thick longitudinal warp yarns interconnected with thin twisted weft yarns at a spacing of $3 \mathrm{~mm}$ using a 4 over/4 under repeating interlacing pattern. The fabric had an areal weight of 180 grams per square meter. The density of flax is $1.4 \mathrm{~g} / \mathrm{cm}^{3}$ [41].

Unidirectional composite laminates were fabricated in $200 \mathrm{~mm} \times 200 \mathrm{~mm}$ steel picture frame moulds with fitting lids using a 50-tonne water cooled hot press built by DSTO Australia. 4 ply laminates $\sim 1.5 \mathrm{~mm}$ thick were used for most of the work but 8 ply laminates $\sim 3 \mathrm{~mm}$ thick were used for impact testing which required specimens of a greater thickness. All composites were fabricated by placing pre-cut plies of unidirectional flax cloth having dimensions of $200 \mathrm{~mm} \times 200 \mathrm{~mm}$ in the picture frame mould. The composites were fabricated from matrix material in the powder form, with the powder being carefully spread using a flat $50 \mathrm{~mm}$ wide soft brush to obtain a uniform distribution.

For the toughened composites, the PBAT and ENR50 were first cryoground into powder using a Spex ${ }^{\circledR}$ Freezer Mill and then mixed with the PHBV matrix powder. The precool time was $10 \mathrm{~min}$, with the grinding then being conducted at $10 \mathrm{~Hz}$ for 3 cycles, each consisting of 2 min grinding followed by 2 min cool down. Due to the self-healing nature of ENR50 [42], $0.1 \mathrm{~g}$ PHBV powder per gram of ENR50 was added for cryogrinding of ENR50 as the PHBV powder prevented ENR50 powder from coalescing back into a solid mass. 
Prior to hot pressing the laminates, the layup was dried (in the mould) in a vacuum oven for 24 hours at $80^{\circ} \mathrm{C}$ to remove moisture. Drying at temperatures of $\sim 80^{\circ} \mathrm{C}$ for at least 24 hours, with or without vacuum, is common practice for PHBV and natural fibres $[13,17,26,30,43]$. The mould was then immediately transferred to the preheated hot press and the laminates compression moulded at $180^{\circ} \mathrm{C}$ and $3.5 \mathrm{MPa}$ for $12 \mathrm{~min}$. A target fibre volume fraction of 0.30 was selected for the study since similar volume fractions have been used widely in the literature. Neat PHBV samples underwent similar preparation with the exception of fibre addition and the cryogenic grinding step.

A differential scanning calorimeter (TA Instruments, DSC Q20) was used to determine the melting temperature $\left(T_{m}\right)$ and crystallization temperature $\left(T_{c}\right)$ for each of the unidirectional composites and also for the neat PHBV. Specimens $7-12 \mathrm{mg}$ in weight were placed in aluminium pans and heated from room temperature to $200^{\circ} \mathrm{C}$ at a rate of $10{ }^{\circ} \mathrm{C} / \mathrm{min}$, then cooled at the same rate to $-25^{\circ} \mathrm{C}$ under $\mathrm{N}_{2}$ purging gas. The specimens were then reheated and cooled at the same rate for a second cycle.

Thermogravimetric analysis (TGA) was conducted on each of the materials listed above with specimens approximately $35 \mathrm{mg}$ in weight using a TGA Q5000. The tests were conducted by heating the samples from room temperature to $600^{\circ} \mathrm{C}$ at a rate of $10{ }^{\circ} \mathrm{C} / \mathrm{min}$, under an air $/ \mathrm{N}_{2}$ mixture.

Tensile testing was performed on parallel-sided specimens measuring $182 \mathrm{~mm} \times 15 \mathrm{~mm}$, with emery paper tabs, according to ASTM D3039. The tests were conducted using an Instron 5982 electromechanical universal testing machine at a crosshead displacement rate of $5 \mathrm{~mm} / \mathrm{min}$. Three layers of 180 grit emery paper positioned flush with the jaws of the grips were used as tabs. An extensometer was used to measure strain for determination of the modulus. Flexural testing was performed according to ASTM D790 using an Instron 5565 electromechanical universal testing machine with a $5 \mathrm{kN}$ load cell. Impact testing was conducted according to ASTM D6110 using a TOYOSEIKI table top pendulum instrument. A minimum of 5 specimens were tested for each of the different tests. Specimens were conditioned according to ASTM D618 Procedure A before mechanical testing.

Microstructural characterization was carried out using standard metallographic techniques. Samples were cut from the composites using a guillotine, mounted in cold setting epoxy resin, ground and polished to a $1 \mu \mathrm{m}$ diamond finish, then examined using a Nikon Epiphot 200 inverted optical microscope. Difficulties were encountered with this technique for the PHBV/ENR/flax specimens due to the rubber particles being plucked out during the polishing process and a modified technique was used. This involved mounting the samples vertically in cold setting resin, sectioning the mount horizontally using a Struers Minitom slow speed saw, then polishing the sectioned face using $1 \mu \mathrm{m}$ diamond paste without any prior grinding steps. This minimized the problem.

Scanning electron microscopy (SEM) was carried out on cryofractured specimens to examine the composite morphology. The work was carried out using a HITACHI S-3400N scanning electron microscope (SEM) operating at $10 \mathrm{kV}$. Prior to examination, all samples were sputter coated with gold in an argon atmosphere using an EMITECH K550x gold coating unit.

\section{Results}

\subsection{Volume Fractions}

The volume fractions of the composites prepared are given in Table 1. There was some variation in the volume fraction which ranged from $0.30-0.35$ for the tensile and flexural samples. The volume fractions of the specimens used for impact testing varied from $0.25-0.32$.

Table 1. Fiber Volume fractions of composites prepared.

\begin{tabular}{ccc}
\hline Sample & Tensile and Flexural Samples & Impact Samples \\
\hline PHBV/flax & 0.30 & 0.32 \\
PHBV/PBAT/flax & 0.32 & 0.25 \\
PHBV/ENR/flax & 0.35 & 0.28 \\
\hline
\end{tabular}




\subsection{Thermal Analysis}

\subsubsection{DSC}

The differential scanning calorimetry (DSC) thermograms from the second heating cycle are shown in Figure 1. The neat PHBV exhibited a melting peak $T_{m}$ at $173^{\circ} \mathrm{C}$ with a shoulder at $165^{\circ} \mathrm{C}$. PHBV/flax exhibited a $T_{m}$ at $172{ }^{\circ} \mathrm{C}$ with a small shoulder at $169^{\circ} \mathrm{C}$. PHBV/PBAT/flax exhibited a $T_{m}$ at $178{ }^{\circ} \mathrm{C}$ with a shoulder approximately $7{ }^{\circ} \mathrm{C}$ lower. A subtle shoulder was also present in the PHBV/PBAT/flax composite at $124{ }^{\circ} \mathrm{C}$. Contrary to the results obtained for PHBV/PBAT/flax, the PHBV/ENR/flax composite showed a reduction in the melting temperature, exhibiting double melting peaks $T_{m 1}$ and $T_{m 2}$ at $155^{\circ} \mathrm{C}$ and $164{ }^{\circ} \mathrm{C}$.

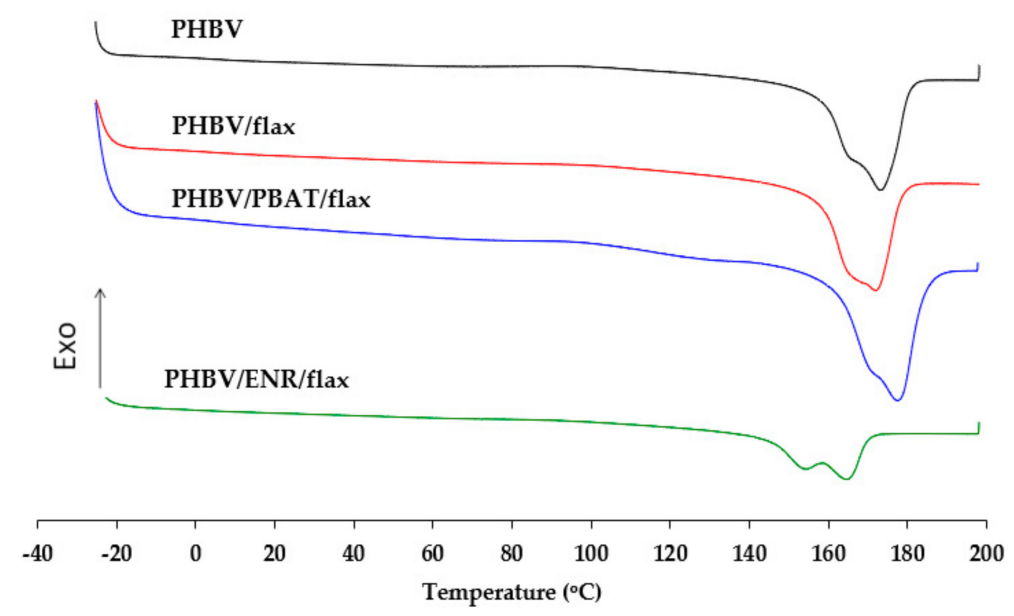

Figure 1. Second cycle DSC thermograms of PHBV, PHBV/flax, PHBV/PBAT/flax and PHBV/ENR/flax.

The thermograms from the cooling cycle are shown in Figure 2. In the cooling cycles, an exothermic crystallization peak $T_{\mathcal{C}}$ was observed at $79^{\circ} \mathrm{C}$ for the neat PHBV. The addition of flax resulted in an $8{ }^{\circ} \mathrm{C}$ increase in $T_{\mathcal{C}}$. However, subsequent addition of both PBAT and ENR to PHBV/flax negated the increase in $T_{\mathcal{c}}$ caused by the addition of flax. The $T_{\mathcal{C}}$ values obtained were 79 and $75{ }^{\circ} \mathrm{C}$ respectively, with the value obtained for PHBV/ENR/flax in fact being lower $\left(4^{\circ} \mathrm{C}\right)$ than that obtained for neat PHBV.

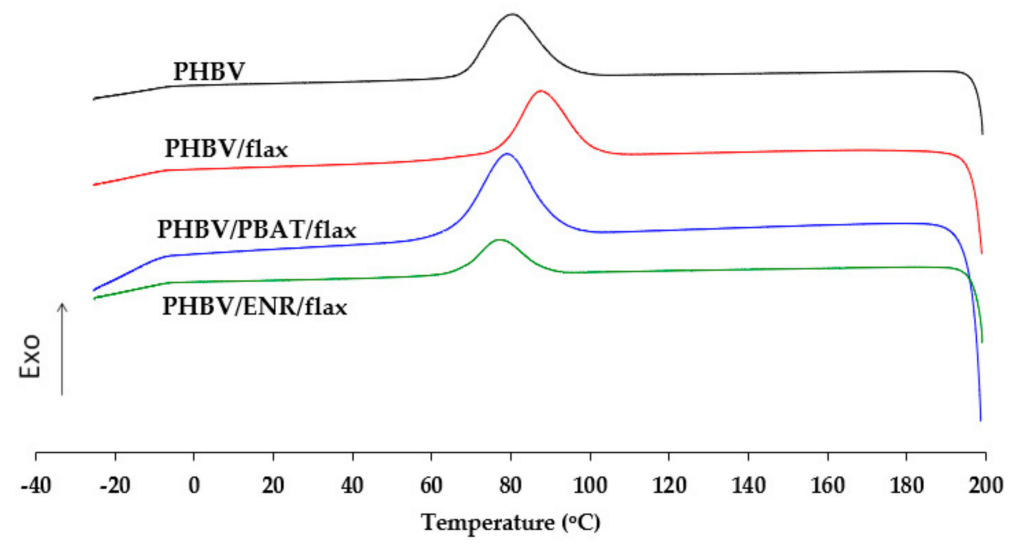

Figure 2. DSC cooling curves of PHBV, PHBV/flax, PHBV/PBAT/flax and PHBV/ENR/flax.

\subsubsection{TGA}

The TG and DTG curves are shown in Figures 3 and 4. Neat PHBV degraded in a single step as indicated by a single abrupt drop in the TG curve and a corresponding single peak in the DTG curve, occurring at $296^{\circ} \mathrm{C}$. The flax fibres showed two degradation steps, preceded by small irregularities in the TG curve, with the DTG peaks being at $346{ }^{\circ} \mathrm{C}$ and $461{ }^{\circ} \mathrm{C}$. A small peak was also evident 
at $333{ }^{\circ} \mathrm{C}$ on the side of the $346^{\circ} \mathrm{C}$ peak. The PHBV/flax, PHBV/PBAT/flax and PHBV/ENR/flax all showed a three-step degradation process with the first DTG peak of each composite occurring at lower temperatures than for the neat PHBV. For PHBV/flax, the first DTG peak was at $286{ }^{\circ} \mathrm{C}$, for PHBV/PBAT/flax at $280^{\circ} \mathrm{C}$ and for PHBV/ENR/flax at $272{ }^{\circ} \mathrm{C}$. The second degradation peak was at $332{ }^{\circ} \mathrm{C}$ for PHBV/flax, at $346^{\circ} \mathrm{C}$ for PHBV/PBAT/flax and at $333^{\circ} \mathrm{C}$ for PHBV/ENR/flax, while the third degradation peak was at $430^{\circ} \mathrm{C}, 430^{\circ} \mathrm{C}$ and $445^{\circ} \mathrm{C}$ for the three composites, respectively. Shoulders were evident in the second and third TGA peaks for PHBV/PBAT/flax and in the third TGA peak for PHBV/ENR/flax. The degradation peaks in the composites corresponding to flax and PHBV were observed to shift to lower temperatures than those observed for neat flax and neat PHBV. It is also noted that the TG curve for the PHBV/flax composite lies between the curve for neat PHBV and that for neat fibre but is much closer to the PHBV curve than to the flax curve.

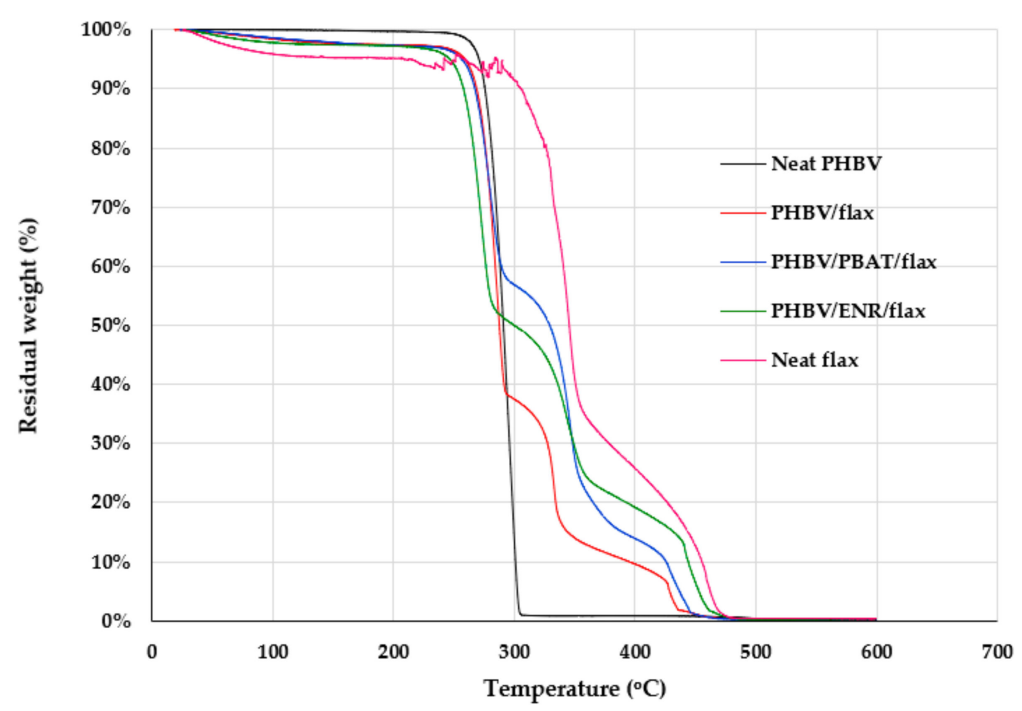

Figure 3. TG curves of PHBV, PHBV/flax, PHBV/PBAT/flax and PHBV/ENR/flax.

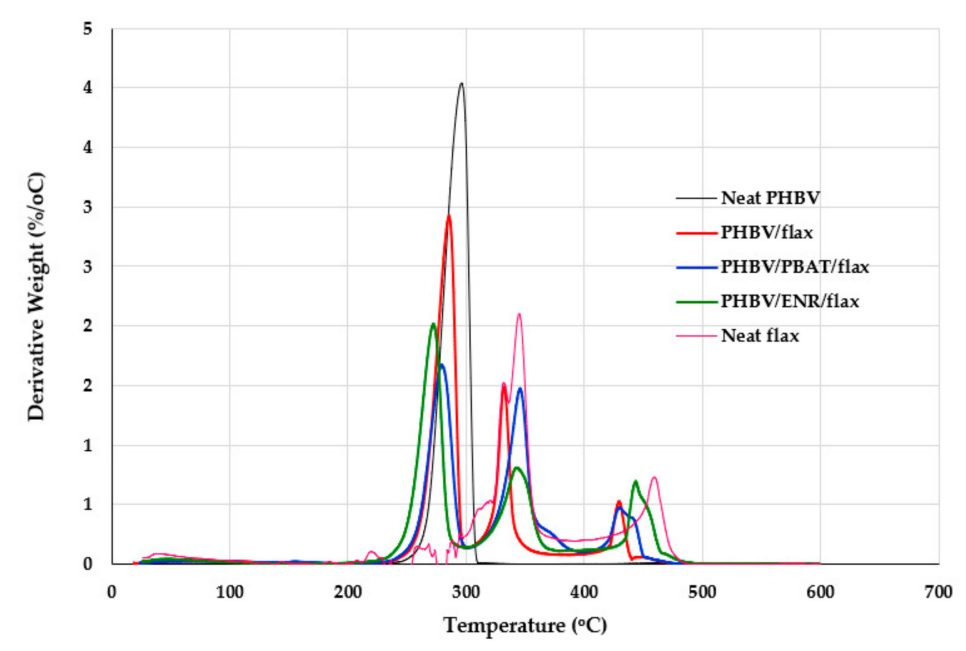

Figure 4. DTG curves of PHBV, PHBV/flax, PHBV/PBAT/flax and PHBV/ENR/flax.

\subsection{Mechanical Properties}

A summary of all mechanical properties is given in Table 2. 
Table 2. Mechanical properties of samples tested.

\begin{tabular}{cccccc}
\hline Sample & $\begin{array}{c}\text { Tensile } \\
\text { Modulus } \\
\text { (GPa) }\end{array}$ & $\begin{array}{c}\text { Tensile } \\
\text { Strength } \\
\mathbf{( M P a )}\end{array}$ & $\begin{array}{c}\text { Flexural } \\
\text { Modulus } \\
\mathbf{( G P a )}\end{array}$ & $\begin{array}{c}\text { Flexural } \\
\text { Strength } \\
\mathbf{( M P a})\end{array}$ & $\begin{array}{c}\text { Impact } \\
\text { resistance } \\
\mathbf{( J / m )}\end{array}$ \\
\hline PHBV & $4.0 \pm 0.2$ & $33.2 \pm 0.6$ & $4.6 \pm 0.2$ & $62.6 \pm 2.8$ & $15 \pm 0.4$ \\
PHBV/flax & $16.9 \pm 2.7$ & $183.1 \pm 24.9$ & $13.1 \pm 2.6$ & $209.7 \pm 13.6$ & $479 \pm 46$ \\
PHBV/PBAT/flax & $14.4 \pm 2.2$ & $177.1 \pm 27.9$ & $12.2 \pm 2.0$ & $153.1 \pm 14.1$ & $369 \pm 39$ \\
PHBV/ENR/flax & $13.3 \pm 1.7$ & $188.1 \pm 12.8$ & $7.4 \pm 2.7$ & $51.6 \pm 17.4$ & $555 \pm 4$ \\
\hline
\end{tabular}

\subsubsection{Tensile}

Representative tensile stress-strain curves for neat PHBV and the three composites are shown in Figure 5. The load drop seen in the curves is due to relaxation during removal of the extensometer. The stress strain curve for neat PHBV showed a small gradual decrease in slope with increasing strain but the stress strain curves for the composites showed two essentially linear regions separated by a knee. The slope of the curves decreased substantially after the knee. The curves for the composites extended to much larger strains than that for the neat PHBV. The neat PHBV had a tensile modulus of 4.0 GPa and a tensile strength of $33.2 \mathrm{GPa}$. The incorporation of fibres into the PHBV dramatically improved all tensile properties with the modulus increasing more than 4 -fold ( $320 \%$ increase) and the strength increasing almost 6 -fold ( $450 \%$ increase). The modulus was $15 \%-21 \%$ lower in the toughened composites than in the untoughened composite but the strength remained the same as that of PHBV/flax.

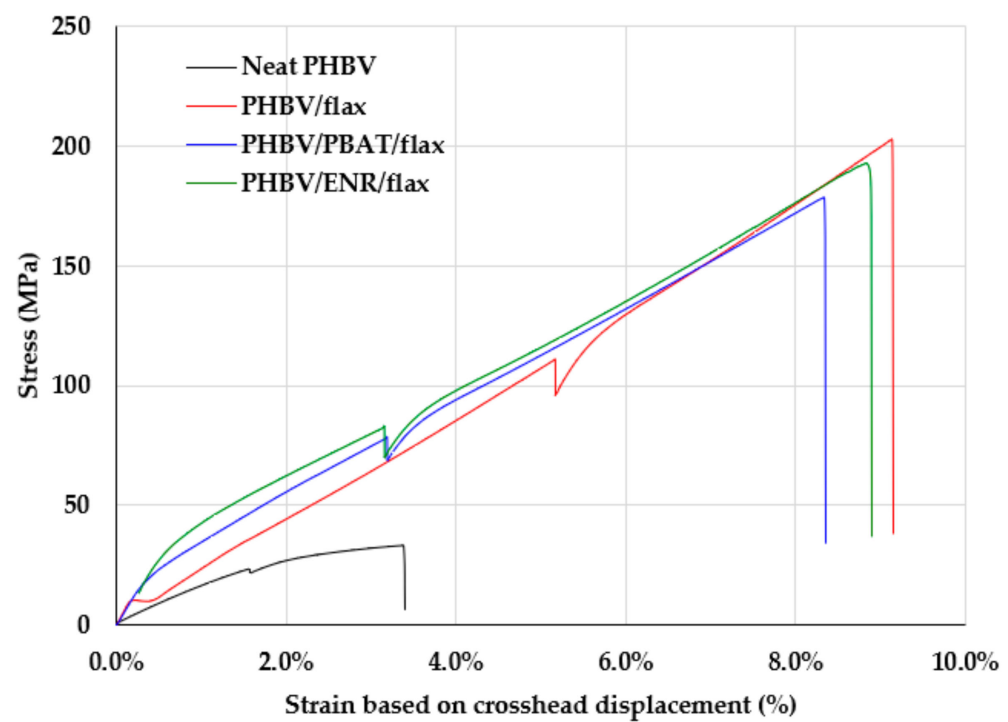

Figure 5. Representative tensile stress-strain curves of PHBV, PHBV/flax, PHBV/PBAT/flax and PHBV/ENR/flax.

\subsubsection{Flexural}

Representative flexural stress-strain curves are shown in Figure 6. Different types of stress strain behaviour were evident amongst the different materials. The neat PHBV failed without yielding (Type (a) behaviour in ASTM D790) and, accordingly, the flexural strength was determined as the stress at failure. Failure was instantaneous in these specimens with the curves showing an abrupt load drop. The PHBV/flax composites also failed without yielding and the flexural strength was determined as above. The PHBV/PBAT/flax specimens showed neither yield nor fracture prior to reaching a strain of 5\% (Type (c) behaviour in ASTM D790) and for these the flexural stress was determined as the stress at a strain of 5\%. The PHBV/ENR/flax sample showed quite different behaviour to that of the other composites. The sample yielded before achieving a strain of 5\% (Type (b) behaviour in ASTM 
D790) and the flexural stress was determined as the stress at yield. Yield in the PHBV/ENR/flax specimens occurred at a strain of $\sim 0.7-1.0 \%$ which was much lower than the strain at the onset of failure ( $3.5-4.5 \%)$ in the PHBV/flax specimens. Moreover, the PHBV/ENR/flax composites showed distinct strain softening which was not observed in the other composites. The flexural modulus and flexural strength of neat PHBV were found to be $4.6 \pm 0.2 \mathrm{GPa}$ and $62.6 \pm 2.8 \mathrm{MPa}$, respectively. Again, the properties were higher for the PHBV/flax composite, with approximately a 3-fold increase in both modulus and strength. The addition of PBAT to the PHBV/flax caused a $7 \%$ reduction in modulus and a $27 \%$ reduction in strength. For the PHBV/ENR/flax specimens, the modulus was only half that of the other composites while the strength was even more dramatically reduced (approximately $70 \%$ reduction), being $18 \%$ lower than even that for the unreinforced PHBV.

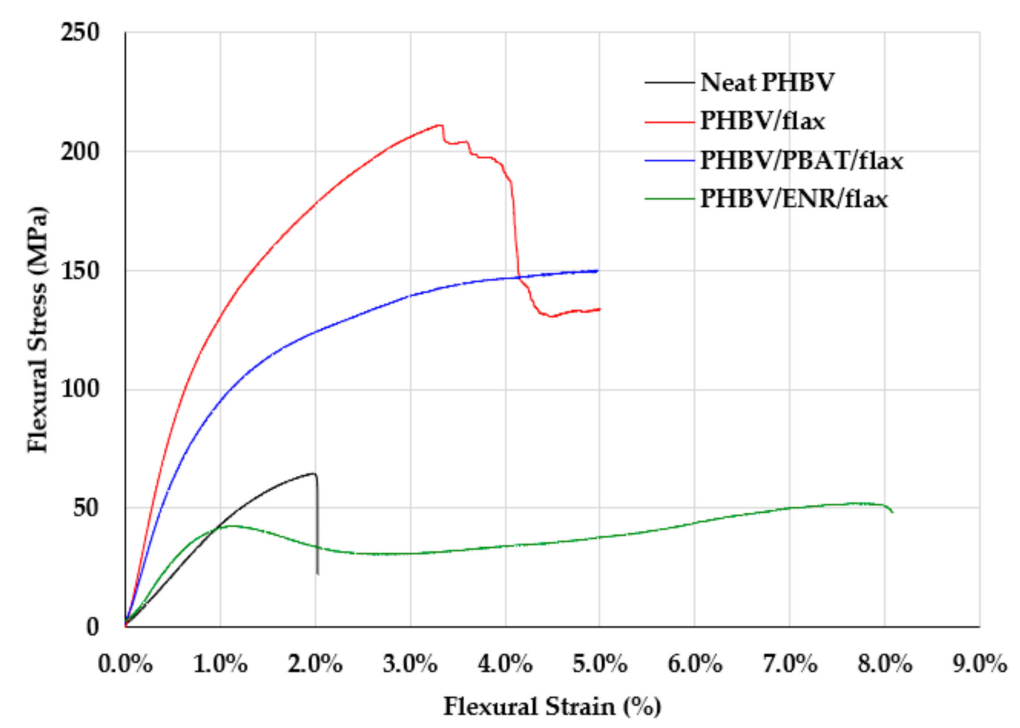

Figure 6. Representative flexural stress-strain curves of PHBV, PHBV/flax, PHBV/PBAT/flax and PHBV/ENR/flax.

\subsubsection{Impact}

The impact strength of the samples is given in Figure 7. The impact resistance was $1.4 \mathrm{~kJ} / \mathrm{m}^{2}$ for the neat PHBV and was increased 24 to 37 -fold in the composites.

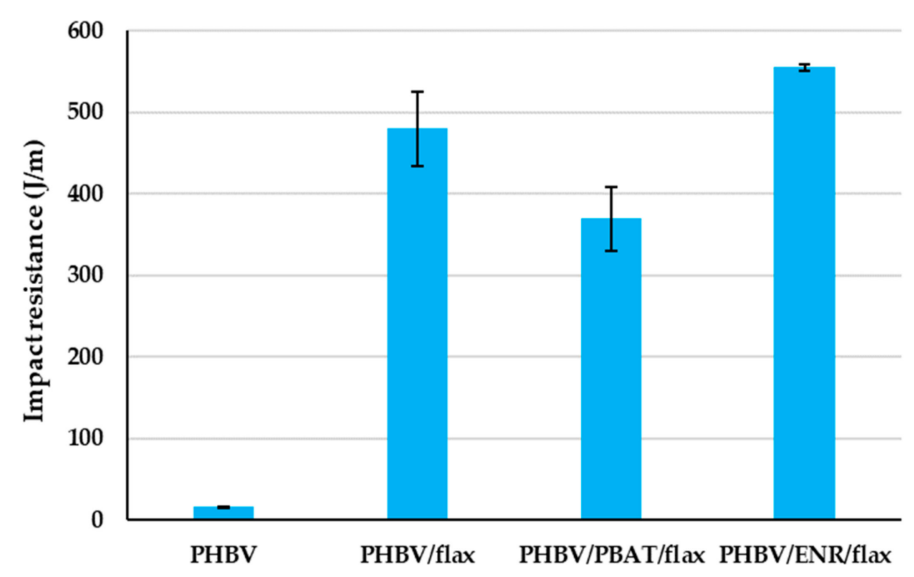

Figure 7. Impact properties of PHBV, PHBV/flax, PHBV/PBAT/flax and PHBV/ENR/flax. 


\subsection{Microscopy}

\subsubsection{Optical}

The longitudinal and transverse microstructures of the three composites are given in Figure 8. The composites can be seen to have a layered structure consisting of fibre rich bands separated by layers of matrix of similar thickness. The fibre yarns were well aligned laterally within the fibre rich bands, as in the original unidirectional fabric. The yarns were circular in cross-section with a diameter of $\sim 200 \mu \mathrm{m}$. The technical fibres within the yarns were typically $\sim 20 \mu \mathrm{m}$ in diameter. The more widely spaced interlacing transverse (weft) yarns could be seen in some cases. The composites were well consolidated with good matrix impregnation of the fibre yarns. The PBAT was well dispersed in the PHBV/PBAT/flax composite with the PBAT particles being essentially circular and typically 20-50 $\mu \mathrm{m}$ in diameter. However, for the PHBV/ENR/flax composites the particles were much larger and generally spanned the distance between the fabric layers $(\sim 200 \mu \mathrm{m})$. Many of the particles were elongated in both the transverse and longitudinal direction and often spanned several fibres.

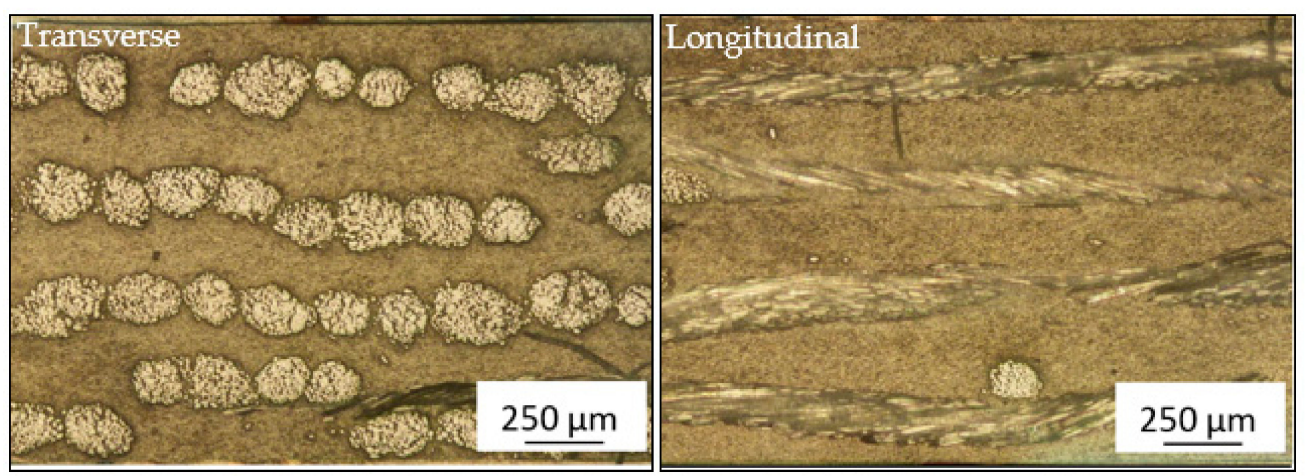

(a)

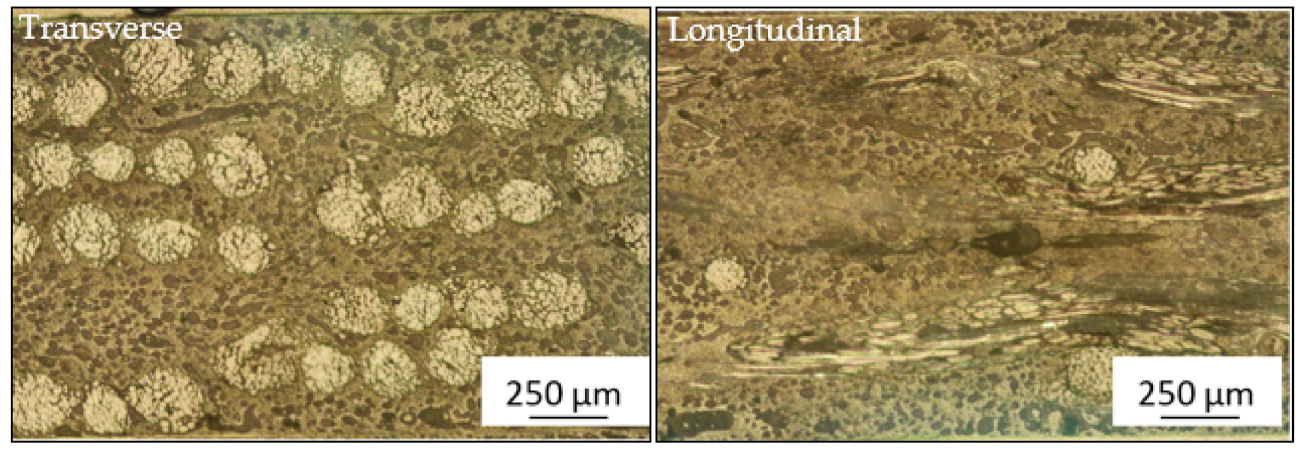

(b)
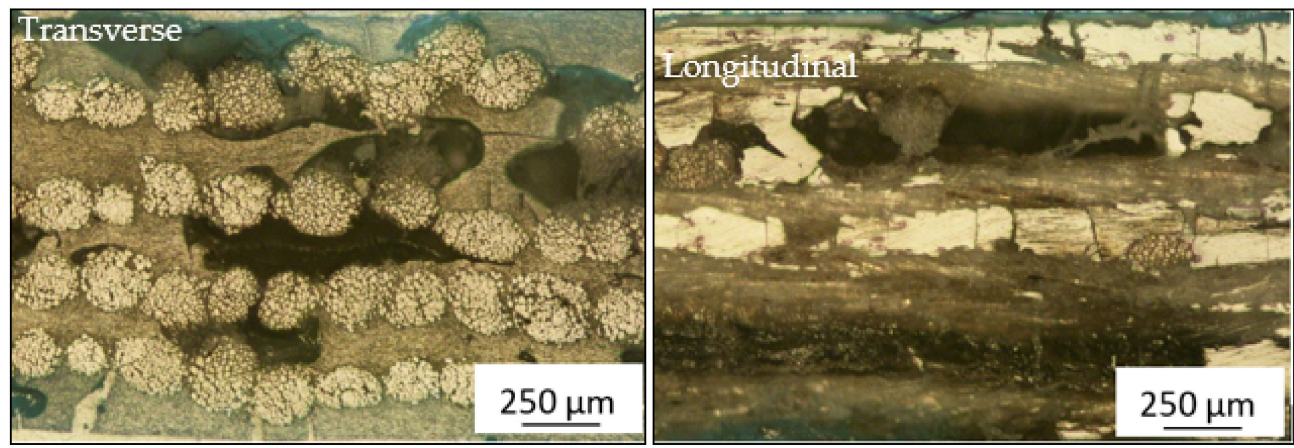

(c)

Figure 8. Optical micrographs of longitudinal and transverse cross sections of (a) PHBV/flax, (b) PHBV/PBAT/flax and (c) PHBV/ENR/flax. 
In view of the very different behaviour observed for the PHBV/ENR/flax composite, a tested sample was sectioned longitudinally along the centreline using the modified metallographic technique described earlier. Tested specimens of the PHBV/flax and PHBV/PBAT/flax were also sectioned for comparison. Low magnification cross sections of the three composites after flexural testing are given in Figure 9. Unlike the other two specimens the PHBV/ENR/flax specimen shows substantial buckling of the fibres on the compression side of the bend. It was also apparent that failure had occurred through a region which was rich in ENR particles having dimensions similar to the inter fabric spacing. A similar kind of buckling was also observed after impact testing, as shown in Figure 10.

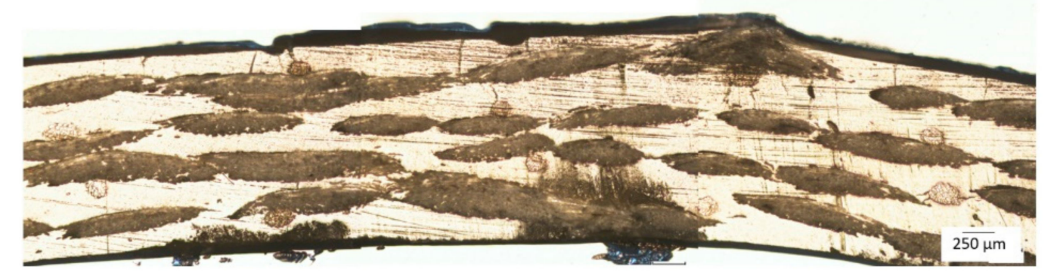

(a)

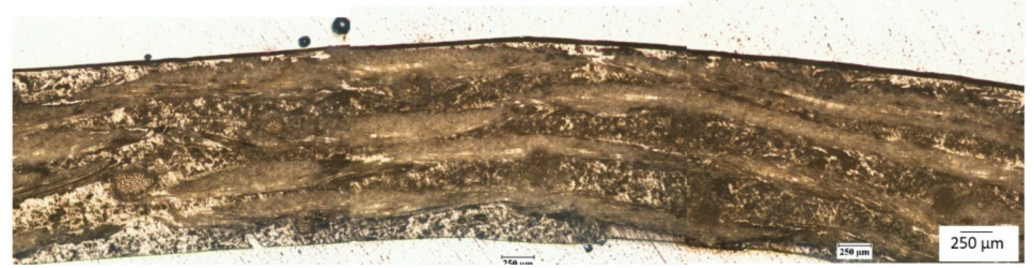

(b)

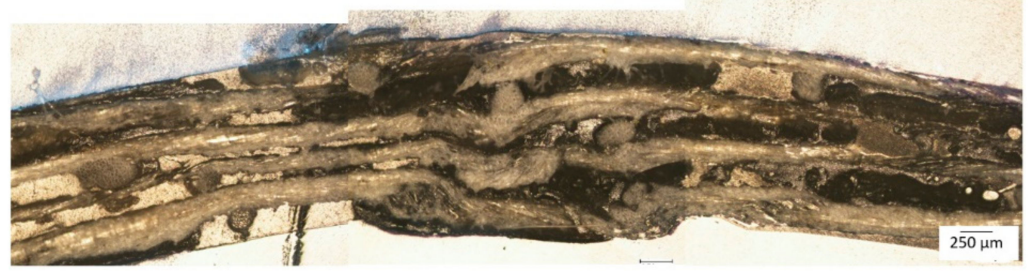

(c)

Figure 9. Low magnification optical micrographs of tested flexural samples of (a) PHBV/flax, (b) PHBV/PBAT/flax and (c) PHBV/ENR/flax.

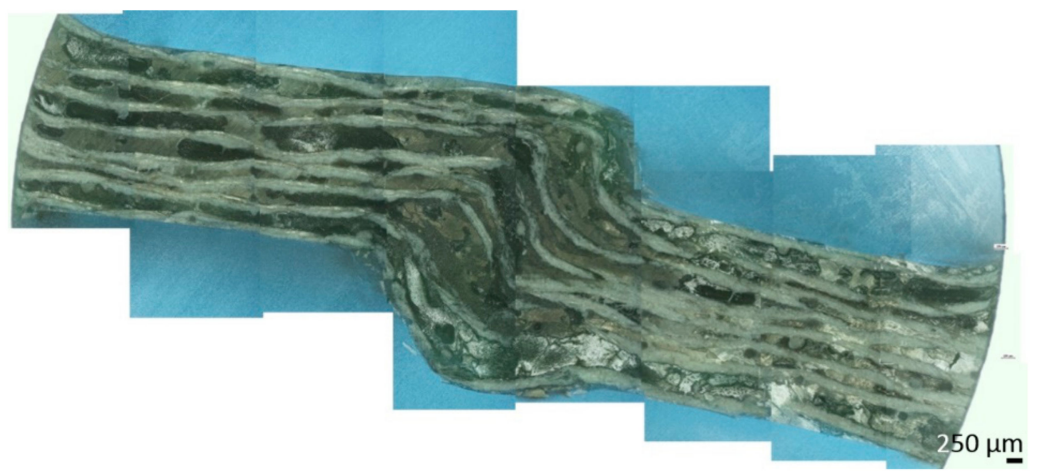

Figure 10. Low magnification optical micrograph of tested impact sample of PHBV/ENR/flax.

\subsubsection{SEM}

Electron micrographs of transverse and longitudinal cross sections of cryofractured samples are given in Figure 11. The PHBV specimen had a fracture surface typical of brittle fracture in polymers [13,17,23,30,31]. The transverse PHBV/flax specimen showed similar brittle characteristics in the matrix with short protrusions of broken yarns and fibre sockets left from fibre pull-out. Remnants of the interlacing weft yarns were apparent in places. Brittle matrix failure with bare fibres and 
fibre imprints was seen in the longitudinal section. These features are considered indicative of weak interfacial bonding. The transverse fracture surface of the PHBV/PBAT/flax specimen showed similar features to that of the PHBV/flax specimen. In this case, imprints from the weft yarns, rather than the yarns themselves, were evident on the fracture surface. Decohesion of some of the larger PBAT particles from the matrix was evident in the longitudinal section. Similar features to those for the PHBV/flax were also observed on the transverse and longitudinal fracture surfaces of the PHBV/ENR/flax specimens. The longitudinal section shows what appears to be a cleaved rubber particle that has cavitated around its perimeter. Importantly, the particle appears to be well bonded to the surrounding material. There are also some features which may be fractured rubber particles on the transverse section.

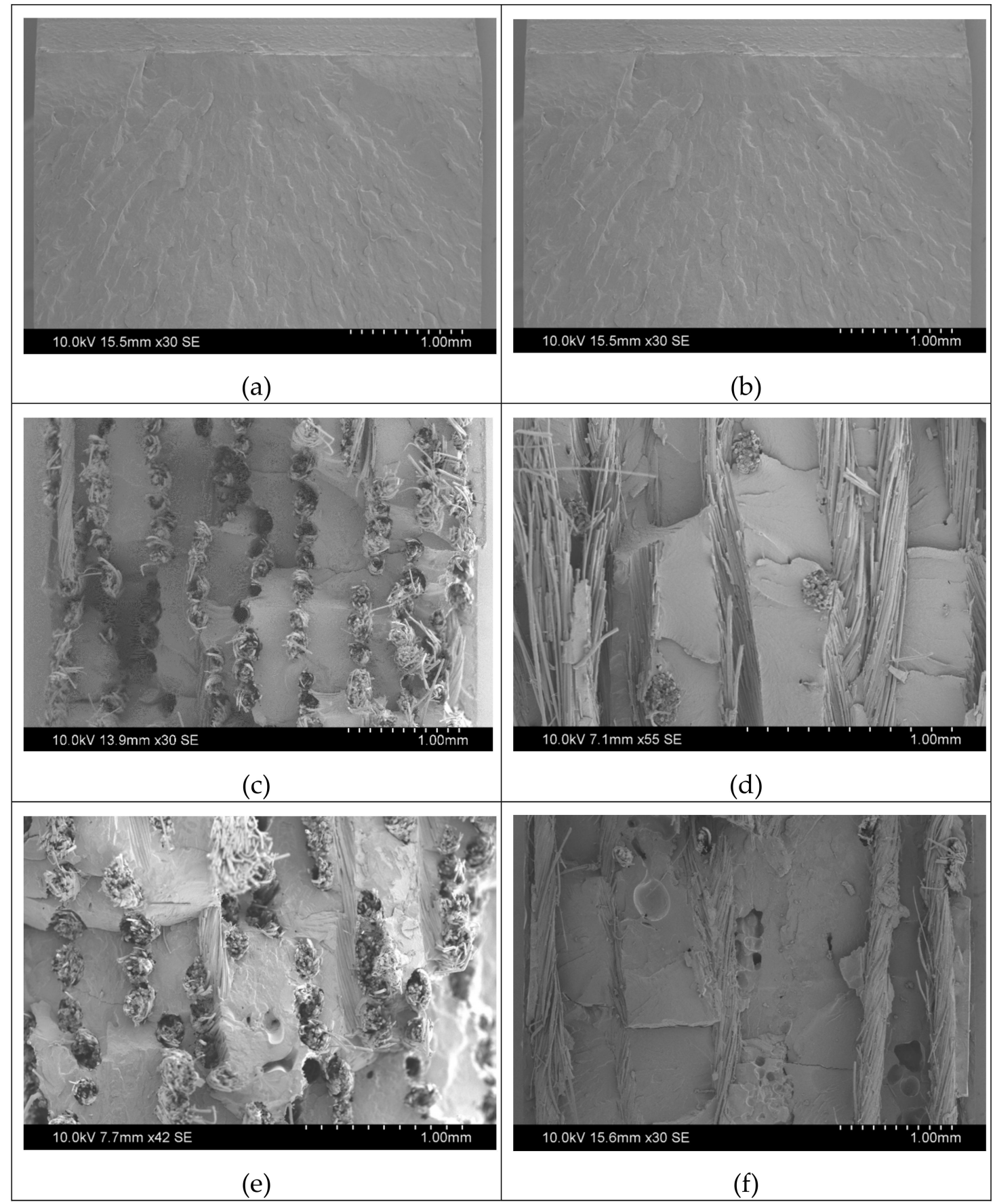

Figure 11. Cont. 


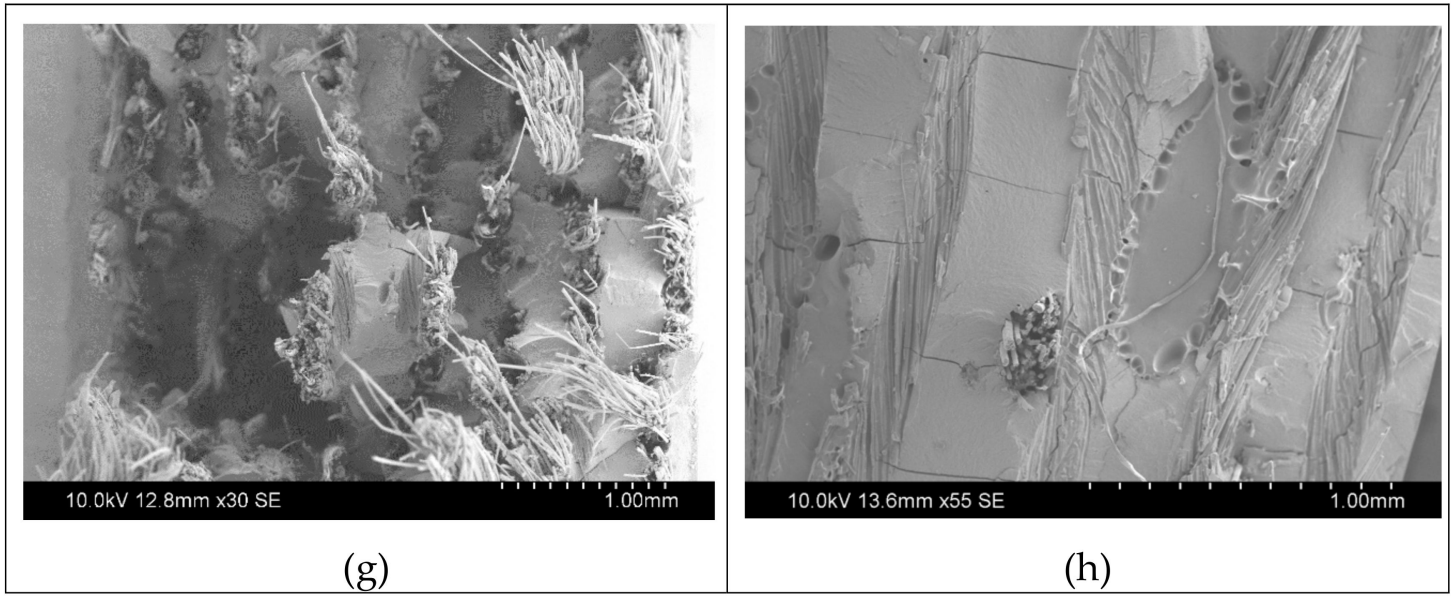

Figure 11. Electron micrographs of longitudinal and transverse cross sections of (a and $\mathbf{b}) \mathrm{PHBV}$, (c and d) PHBV/flax, (e and f) PHBV/PBAT/flax and (g and $\mathbf{h}$ ) PHBV/ENR/flax obtained by cryofracturing.

\section{Discussion}

\subsection{Thermal Analysis}

\subsubsection{DSC}

The $T_{m}$ decreased slightly with incorporation of the flax fibres into PHBV. This is consistent with the findings of Srithep et al. [17] for PHBV/cellulose composites who attributed the decrease to degradation of the PHBV caused by hydroxyl groups on the cellulose fibres triggering hydrolysis of the PHBV at elevated temperature. An increase in $T_{m}$ occurred with the addition of PBAT to PHBV/flax. The increase is considered likely to be due to a refinement of the crystalline structure of PHBV created by PBAT addition, since the PBAT particles were finely dispersed throughout the matrix (Figure 8) and could have acted as a nucleating agent. The reduction in melting temperature caused by ENR addition is consistent with the findings of Kuntanoo et al. [44] for an unreinforced PHBV/natural rubber latex 50:50 blend. They found that the $T_{m}$ was reduced by $3{ }^{\circ} \mathrm{C}$ from that of neat PHBV. The authors also reported a reduction in the degree of crystallinity from $56.25 \%$ to $5.65 \%$. This indicates that the addition of natural rubber to the PHBV caused an amorphization of the crystalline structure and the same could be expected in the present study. The addition of flax to PHBV increased $T_{c}$. This has been attributed previously to the fibres acting as nucleation sites for crystallites to form, allowing peak crystallization to take place at a higher $T_{c}[20,23,24,35]$. The crystallization temperatures for the PHBV/PBAT/flax and PHBV/ENR/flax composites were noticeably lower than for the PHBV/flax. This could be due to the toughening agents hindering the crystallization process, especially in the case of PHBV/ENR/flax.

\subsubsection{TGA}

Neat PHBV exhibited single step thermal degradation, with the degradation peak being at $296{ }^{\circ} \mathrm{C}$. This is in reasonable agreement with results reported previously which lie in the range $245.8-298^{\circ} \mathrm{C}[14,16,22,24,30]$. The flax fibres showed a two-step thermal degradation, with degradation peaks (peaks in derivative TG curve) at $346{ }^{\circ} \mathrm{C}$ and $461{ }^{\circ} \mathrm{C}$. The first peak has been attributed to degradation of cellulose while the second peak has been attributed to degradation of non-cellulosic components [45]. The PHBV/flax, PHBV/PBAT/flax and PHBV/ENR/flax all showed a three-step degradation process. The first peak has been reported in previous work to correspond to degradation of the PHBV and the second peak to degradation of the flax $[4,16]$. In the PHBV/flax composite, the third peak, which was not reported in previous work $[4,16]$, is considered to be due to the second degradation peak seen in the flax fibres. The third peak in the PHBV/PBAT/flax and PHBV/ENR/flax composites is attributed to degradation of PBAT [28,37] and ENR [46], respectively. The shoulder on the third peak in the PHBV/PBAT/flax and PHBV/ENR/flax composites is considered to represent 
the third degradation step for the flax. The shift of the flax and PHBV peaks to lower temperatures in the composites has been attributed in previous studies to a mutual degradation process of both components initiated by hydroxyl groups on the cellulose fibres triggering hydrolysis of the PHBV at elevated temperature $[17,35]$. This results in the production of crotonic acid which in turn degrades the fibres. The proximity of the PHBV/flax composite TG curve to either the flax TG curve or the neat PHBV TG curve depends on the fibre volume fraction in the composite, with the composite curve being closer to the neat material curve whose volume fraction is higher [36].

\subsection{Mechanical Properties}

\subsubsection{Tensile}

A very substantial improvement in mechanical properties was obtained as a result of addition of flax fibres to the PHBV. This is due, at least principally, to the very superior properties of the fibres. There may also have been a minor contribution from increased crystallinity resulting from enhanced nucleation at the fibres $[19,20,23,24,35]$. The incorporation of $30 \mathrm{vol} . \%$ of the toughening agents PBAT and ENR into the PHBV matrix of the composites resulted in $15 \%-21 \%$ reductions in modulus but no appreciable change in strength. It is noted, however, that both the PBAT and PHBV toughened composites had slightly higher fibre volume fractions ( 0.32 and 0.35 , respectively) than the untoughened composite (0.30). To account for this effect, the modulus of the untoughened composite was calculated for the same fibre volume fractions as in the toughened composites. This was done by back calculating the modulus of the fibre yarns from the measured modulus of the untoughened composite and the measured modulus of neat PHBV using the rule of mixtures, Equation (1).

$$
E_{c}=E_{f} V_{f}+\left(1-V_{f}\right) E_{m}
$$

where:

$V=$ volume fraction of the phase

$E=$ tensile modulus, $\mathrm{GPa}$

$c, f$ and $m$ are subscripts representing composite, fibre and matrix, respectively

This gave a value of $47.1 \mathrm{GPa}$ for the fibre yarns. The modulus of the untoughened composite was then recalculated at the volume fractions of the two toughened composites of 0.32 and 0.35 , again using the rule of mixtures. The values obtained were $17.8 \mathrm{GPa}$ and $19.1 \mathrm{GPa}$, respectively. The Student's t-test indicated that, at the same volume fractions, the modulus for the PHBV/PBAT/flax composite was not significantly different to that of the PHBV/flax composite but the modulus of the PHBV/ENR/flax composite was 30\% lower than that of PHBV/flax. While only the modulus for PHBV/ENR/flax was significantly lower than that for PHBV/flax, some reduction in modulus would, in fact, be expected for both the PBAT and ENR toughened composites because of the lower moduli of the toughening agents- $-0.8 \mathrm{GPa}$ [47] and $0.008 \mathrm{GPa}$ [48] for PBAT and ENR, respectively. The strength of the untoughened composite was similarly calculated for the same volume fractions as the toughened composites. Student's t-test revealed that there was no significant difference between the tensile strength of either the PHBV/ENR/flax composite or the PHBV/PBAT/flax composite compared with that of the PHBV/flax composites. This result is to be expected since strength of unidirectional composites is a fibre dominated property and differences in the strength of the untoughened and toughened matrices would be expected to have minimal effect. As noted earlier, the stress-strain curves for the composites exhibited a distinct knee. Similar behaviour has been reported previously by Hughes et al. $[49,50]$ who attributed its occurrence to irreversible deformation resulting from "re-organization of cellulose fibrils in the direction of the fibre axis" and extension of kink band defects in the fibres. 


\subsubsection{Flexure}

The addition of fibres to PHBV also improved the flexural properties although the improvements were more modest than the improvements in tensile properties. This would appear to reflect the greater influence of the matrix properties under flexural loading. The addition of the toughening agents then produced decreases in the flexural properties of the composites, with the strength being decreased by $7 \%$ in the PHBV/PBAT/flax composite while the modulus was decreased by $27 \%$. More substantial decreases were observed in the PHBV/ENR/flax composite with the reductions being $43 \%$ in the flexural modulus and $75 \%$ in the flexural strength. The strength was, in fact, deceased to a level such that it was no longer significantly different to that of neat PHBV. However, it was apparent that the flexural stress strain behaviour of the PHBV/ENR/flax composites was quite different to that of the other composites, with the peak stress occurring at a strain of $\sim 1 \%$, compared with $>3 \%$ for PHBV/flax and $>5 \%$ for PHBV/PBAT/flax. The PHBV/ENR/flax sample showed distinct fibre buckling on the compression side of the sample, as seen in the micrographs in Figure 9, while this was not observed for the other composites. It is considered therefore that the anomalous behaviour of the PHBV/ENR/flax composite was due to the specimens undergoing premature failure in compression on the compression side of the specimens. According to Sun and Jun [51], the stress at which compression failure occurs in unidirectional composites is dependent on the shear modulus of the matrix. The rubber particle rich zone seen in the specimen in Figure 9. would cause a substantial localized reduction in the modulus, which in turn would promote premature compression failure. Thus, it is considered that the poor flexural properties of the PHBV/ENR/flax are a consequence of the coarseness of the rubber particles. The rubber particles would be expected to have a lesser effect on the tensile strength, as observed. It would also be expected that had the rubber particles been the same size as the PBAT particles the flexural behaviour would have been substantially improved.

\subsubsection{Impact}

As for the tensile and flexure specimens, the impact specimens had somewhat different volume fractions in the different composites, with the volume fraction of PHBV/flax being 0.32, that of PHBV/PBAT flax being 0.25 and that of PHBV/ENR/flax being 0.28 . To account for this, the results were normalized to a volume fraction of $30 \%$. This was done using a linear relationship between toughness and volume fraction [52]. The addition of unidirectional flax fibres caused an increase in the impact resistance of PHBV by a factor of more than 20. Surprisingly, the addition of PBAT gave no further increase. This is probably because any improvement due to matrix toughening is greatly overshadowed by the toughening imparted by the fibre reinforcement. A significant increase in impact resistance of $34 \%$ was however achieved with the addition of ENR to the PHBV/flax composite. However, the samples failed in quite a different manner to the PHBV/flax and PHBV/PBAT/flax, simply deforming by bending and twisting rather than undergoing fracture. This resulted in kinking of the fibres as shown in Figure 10. As in the flexure specimens for the PHBV/ENR/flax composite, the kinking is considered to have resulted from compression failure on the compression side of the bend. As a result, tensile separation did not occur on the tension side of the bend, unlike in the PHBV/flax and PHBV/PBAT/flax. As for the flexure specimens, large rubber particles with a size similar to the interfabric spacing were seen within the kink. The kinking process is a progressive, rather than abrupt, failure process and should, therefore, result in higher energy absorption.

\subsection{Microscopy}

Examination of cryofractured surfaces revealed that the rubber particles were well bonded to the PHBV matrix. Bare fibres and clean fibre imprints on the cryofracture surfaces indicated that the fibres were only weakly bonded to the matrix in all the composites. This is common for uncompatabilized composites and is attributed to the hydrophilic and hydrophobic nature of the natural fibres and the PHBV matrix, respectively $[7,16,22,35,53]$. The substantial fibre pull-out seen in the cryofractured 
specimens is further indication of weak interfacial bonding, which supports the mechanical property results above $[19,20,36]$.

\section{Conclusions}

The addition of unidirectional flax to PHBV produced very substantial increases in tensile, flexure and impact properties, whilst producing minimal change in the thermal properties. The addition of PBAT to PHBV/unidirectional flax composites did not cause any significant changes in thermal or mechanical properties. Similarly, the addition of ENR, did not cause any significant changes in the thermal properties. However, it reduced the tensile modulus, as well as the flexural modulus and strength but produced a significant increase in impact strength. The different behaviour of the PHBV/ENR/flax composites is considered to be a consequence of the coarse size of the ENR particles which could not be reduced to the same size as the PBAT particles for the cryogrinding regime used.

Author Contributions: Conceptualization, Z.Z. and A.C.; Data curation, Z.Z.; Investigation, Z.Z.; Methodology, Z.Z.; Project administration, A.C.; Resources, Z.Z. and A.C.; Supervision, A.C.; Visualization, Z.Z.; Writing-original draft, Z.Z.; Writing-review \& editing, A.C.

Funding: This research received no external funding.

Acknowledgments: Technical support in performing the DSC and TGA tests was provided by Eh Hau Pan from the Centre for Advanced Macromolecular Design (CAMD), UNSW. Technical support in performing mechanical tests was provided by Bill Joe from the School of Materials Science and Engineering, UNSW. Manufacturing of a compression moulding die to produce impact specimens was provided by Pritipal Baweja from the Chemical Sciences Workshop, UNSW. Technical support with electron microscopy was provided by Dr. Simon Hager from the Electron Microscopy Unit (EMU), UNSW.

Conflicts of Interest: The authors declare no conflict of interest.

\section{References}

1. La Mantia, F.P.; Morreale, M. Green composites: A brief review. Compos. Part A Appl. Sci. Manuf. 2011, 42, 579-588. [CrossRef]

2. Ball, P. Material Witness: E-waste not. Nat. Mater. 2003, 2, 76. [CrossRef]

3. Modi, S.J.; Cornish, K.; Koelling, K.; Vodovotz, Y. Fabrication and improved performance of poly(3-hydroxybutyrate-co-3-hydroxyvalerate) for packaging by addition of high molecular weight natural rubber. J. Appl. Polym. Sci. 2016, 133, 1-9. [CrossRef]

4. Luo, S.; Netravali, A.N. Interfacial and mechanical properties of environment-friendly "green" composites made from pineapple fibers and poly(hydroxybutyrate-co-valerate) resin. J. Mater. Sci. 1999, 34, 3709-3719. [CrossRef]

5. Adam, J.; Korneliusz, B.A.; Agnieszka, M. Dynamic mechanical thermal analysis of biocomposites based on PLA and PHBV-A comparative study to PP counterparts. J. Appl. Polym. Sci. 2013, 130, 3175-3183. [CrossRef]

6. Bledzki, A.K.; Jaszkiewicz, A. Mechanical performance of biocomposites based on PLA and PHBV reinforced with natural fibres-A comparative study to PP. Compos. Sci. Technol. 2010, 70, 1687-1696. [CrossRef]

7. Shibata, M.; Takachiyo, K.-I.; Ozawa, K.; Yosomiya, R.; Takeishi, H. Biodegradable polyester composites reinforced with short abaca fiber. J. Appl. Polym. Sci. 2002, 85, 129-138. [CrossRef]

8. Hermida, E.B.; Mega, V.I. Transcrystallization kinetics at the poly(3-hydroxybutyrate-co-3-hydroxyvalerate)/ hemp fibre interface. Compos. Part A Appl. Sci. Manuf. 2007, 38, 1387-1394. [CrossRef]

9. Keller, A. Compounding and mechanical properties of biodegradable hemp fibre composites. Compos. Sci. Technol. 2003, 63, 1307-1316. [CrossRef]

10. Michel, A.; Billington, S. Nonlinear Constitutive Model for Anisotropic Biobased Composite Materials. J. Eng. Mech. 2014, 140. [CrossRef]

11. Shibata, M.; Oyamada, S.; Kobayashi, S.; Yaginuma, D.; Shibata, M.; Oyamada, S.; Kobayashi, S.; Yaginuma, D. Mechanical composites and biodegragability of green composites based on biodegradable polyesters and lyocell fabric. J. Appl. Polym. Sci. 2004, 92, 3857-3863. [CrossRef] 
12. Bourban, C.; Karamuk, E.; de Fondaumiere, M.J.; Ruffieux, K.; Mayer, J.; Wintermantel, E. Processing and Characterization of a New Biodegradable Composite Made of a PHB/V Matrix and Regenerated Cellulosic Fibers. J. Envir. Polym. Degrad. 1997, 5, 159-166.

13. Russo, P.; Carfagna, C.; Cimino, F.; Acierno, D.; Persico, P. Biodegradable Composites Reinforced with Kenaf Fibers: Thermal, Mechanical, and Morphological Issues. Adv. Polym. Technol. 2013, 32, E313-E322. [CrossRef]

14. Persico, P.; Acierno, D.; Carfagna, C.; Cimino, F.; Persico, P.; Acierno, D.; Carfagna, C.; Cimino, F. Mechanical and Thermal Behaviour of Ecofriendly Composites Reinforced by and Fibers. Int. J. Polym. Sci. 2011, 2011, 1-7. [CrossRef]

15. Buzarovska, A.; Bogoeva-Gaceva, G.; Grozdanov, A.; Avella, M.; Gentile, G.; Errico, M. Crystallization behavior of poly(hydroxybytyrate-co-valerate) in model and bulk PHBV/kenaf fiber composites. J. Mater. Sci. 2007, 42, 6501-6509. [CrossRef]

16. Avella, M.; Bogoeva-Gaceva, G.; Buzarovska, A.; Errico, M.E.; Gentile, G.; Grozdanov, A. Poly(3-hydroxybutyrateco-3-hydroxyvalerate)-based biocomposites reinforced with kenaf fibers. J. Appl. Polym. Sci. 2007, 104, 3192-3200. [CrossRef]

17. Srithep, Y.; Ellingham, T.; Peng, J.; Sabo, R.; Clemons, C.; Turng, L.-S.; Pilla, S. Melt compounding of poly (3-hydroxybutyrate-co-3-hydroxyvalerate)/ nanofibrillated cellulose nanocomposites. Polym. Deg. Stabil. 2013, 98, 1439-1449. [CrossRef]

18. Jiang, L.; Chen, F.; Qian, J.; Huang, J.; Wolcott, M.; Liu, L.; Zhang, J. Reinforcing and toughening effects of bamboo pulp fiber on poly(3-hydroxybutyrate-co-3-hydroxyvalerate) fiber composites. Ind. Eng. Chem. Res. 2010, 49, 572-577. [CrossRef]

19. Jiang, L.; Huang, J.; Qian, J.; Chen, F.; Zhang, J.; Wolcott, M.P.; Zhu, Y. Study of poly(3-hydroxybutyrate-co-3hydroxyvalerate) (PHBV)/bamboo pulp fiber composites: Effects of nucleation agent and compatibilizer. J. Polym. Environ. 2008, 16, 83-93. [CrossRef]

20. Singh, S.; Mohanty, A.K.; Sugie, T.; Takai, Y.; Hamada, H.; Singh, S.; Mohanty, A.K.; Sugie, T.; Takai, Y.; Hamada, H. Renewable resource based biocomposites from natural fiber and polyhydroxybutyrate-co-valerate (PHBV) bioplastic. Compos. Part A Appl. Sci. Manuf. 2008, 39, 875-886. [CrossRef]

21. Javadi, A.; Srithep, Y.; Pilla, S.; Lee, J.; Gong, S.; Turng, L.-S. Processing and characterization of solid and microcellular PHBV/coir fiber composites. Mater. Sci. Eng. C 2010, 30, 749-757. [CrossRef]

22. Batista, K.C.; Silva, D.A.K.; Coelho, L.A.F.; Pezzin, S.H.; Pezzin, A.P.T.; Batista, K.C.; Silva, D.A.K.; Coelho, L.A.F.; Pezzin, S.H.; Pezzin, A.P.T. Soil Biodegradation of PHBV/Peach Palm Particles Biocomposites. J. Polym. Environ. 2010, 18, 346-354. [CrossRef]

23. Yu, H.-Y.; Qin, Z.-Y.; Liu, L.; Yang, X.-G.; Zhou, Y.; Yao, J.-M. Comparison of the reinforcing effects for cellulose nanocrystals obtained by sulfuric and hydrochloric acid hydrolysis on the mechanical and thermal properties of bacterial polyester. Compos. Sci. Technol. 2013, 87, 22-28. [CrossRef]

24. Yu, H.-Y.; Qin, Z.-Y.; Liu, Y.-N.; Chen, L.; Liu, N.; Zhou, Z. Simultaneous improvement of mechanical properties and thermal stability of bacterial polyester by cellulose nanocrystals. Carbohydr. Polym. 2012, 89, 971-978. [CrossRef]

25. Martínez-Sanz, M.; Villano, M.; Oliveira, C.; Albuquerque, M.G.E.; Majone, M.; Reis, M.; Lopez-Rubio, A.; Lagaron, J.M. Characterization of polyhydroxyalkanoates synthesized from microbial mixed cultures and of their nanobiocomposites with bacterial cellulose nanowhiskers. New Biotechnol. 2013, 31, 364-376, In press. [CrossRef]

26. Zhang, K.; Nagarajan, V.; Zarrinbakhsh, N.; Mohanty, A.K.; Misra, M. Co-injection molded new green composites from biodegradable polyesters and miscanthus fibers. Macromol. Mater. Eng. 2014, 299, 436-446. [CrossRef]

27. Zhang, K.; Misra, M.; Mohanty, A.K. Toughened Sustainable Green Composites from Poly(3-hydroxybutyrate-co3-hydroxyvalerate) Based Ternary Blends and Miscanthus Biofiber. ACS Sustain. Chem. Eng. 2014, 2, 2345-2354. [CrossRef]

28. Nagarajan, V.; Mohanty, A.K.; Misra, M. Sustainable green composites: Value addition to agricultural residues and perennial grasses. ACS Sustain. Chem. Eng. 2013, 1, 325-333. [CrossRef]

29. Nagarajan, V.; Misra, M.; Mohanty, A.K. New engineered biocomposites from poly(3-hydroxybutyrate-co-3hydroxyvalerate) (PHBV)/poly(butylene adipate-co-terephthalate) (PBAT) blends and switchgrass: Fabrication and performance evaluation. Ind. Crops Prod. 2013, 42, 461-468. [CrossRef] 
30. Rossa, L.V.; Scienza, L.C.; Zattera, A.J. Effect of curaua fiber content on the properties of poly(hydroxybutyrate -co-valerate) composites. Polym. Compos. 2013, 34, 450-456. [CrossRef]

31. Berthet, M.A.; Commandre, J.M.; Rouau, X.; Gontard, N.; Angellier-Coussy, H. Torrefaction treatment of lignocellulosic fibres for improving fibre/matrix adhesion in a biocomposite. Mater. Des. 2016, 92, $223-232$. [CrossRef]

32. Ahankari, S.S.; Mohanty, A.K.; Misra, M. Mechanical behaviour of agro-residue reinforced poly(3-hydroxybutyrate-co-3-hydroxyvalerate), (PHBV) green composites: A comparison with traditional polypropylene composites. Compos. Sci. Technol. 2011, 71, 653-657. [CrossRef]

33. Avella, M.; La Rota, G.; Martuscelli, E.; Raimo, M.; Sadocco, P.; Elegir, G.; Riva, R. Poly(3-hydroxybutyrate-co3-hydroxyvalerate) and wheat straw fibre composites: Thermal, mechanical properties and biodegradation behaviour. J. Mater. Sci. 2000, 35, 829-836. [CrossRef]

34. Srubar, W.V.; Pilla, S.; Wright, Z.C.; Ryan, C.A.; Greene, J.P.; Frank, C.W.; Billington, S.L. Mechanisms and impact of fiber-matrix compatibilization techniques on the material characterization of PHBV/oak wood flour engineered biobased composites. Compos. Sci. Technol. 2012, 72, 708-715. [CrossRef]

35. Singh, S.; Mohanty, A.K.; Misra, M. Hybrid bio-composite from talc, wood fiber and bioplastic: Fabrication and characterization. Compos. Part A Appl. Sci. Manuf. 2010, 41, 304-312. [CrossRef]

36. Singh, S.; Mohanty, A.K. Wood fiber reinforced bacterial bioplastic composites: Fabrication and performance evaluation. Compos. Sci. Technol. 2007, 67, 1753-1763. [CrossRef]

37. Javadi, A.; Srithep, Y.; Lee, J.; Pilla, S.; Clemons, C.; Gong, S.; Turng, L.-S. Processing and characterization of solid and microcellular PHBV/PBAT blend and its RWF/nanoclay composites. Compos. Part A Appl. Sci. Manuf. 2010, 41, 982-990. [CrossRef]

38. Javadi, A.; Kramschuster, A.J.; Pilla, S.; Lee, J.; Gong, S.; Turng, L.-S. Processing and characterization of microcellular PHBV/PBAT blends. Polym. Eng. Sci. 2010, 50, 1440-1448. [CrossRef]

39. Savadekar, N.R.; Kadam, P.G.; Mhaske, S.T. Studies on the effect of nano-alumina on the performance properties of poly(butylene adipate-co-terephthalate) composite films. J. Thermopl. Compos. Mater. 2015, 28, 1522-1536. [CrossRef]

40. Mohamad, Z.; Ismail, H.; Chantara Thevy, R. Characterization of Epoxidized Natural Rubber/Ethylene Vinyl Acetate (ENR-50/EVA) blend: Effect of blend ratio. J. Appl. Polym. Sci. 2006, 99, 1504-1515. [CrossRef]

41. Vanleeuw, B.; Carvelli, V.; Barburski, M.; Lomov, S.V.; van Vuure, A.W. Quasi-unidirectional flax composite reinforcement: Deformability and complex shape forming. Compos. Sci. Technol. 2015, 110, 76-86. [CrossRef]

42. Rahman, M.A.; Sartore, L.; Bignotti, F.; Di Landro, L. Autonomic self-healing in epoxidized natural rubber. ACS Appl. Mater. Interf. 2013, 5, 1494-1502. [CrossRef]

43. Berthet, M.A.; Angellier-Coussy, H.; Chea, V.; Guillard, V.; Gastaldi, E.; Gontard, N. Sustainable food packaging: Valorising wheat straw fibres for tuning PHBV-based composites properties. Compos. Part A Appl. Sci. Manuf. 2015, 72, 139-147. [CrossRef]

44. Kuntanoo, K.; Promkotra, S.; Kaewkannetra, P. Fabrication of novel polyhydroxybutyrate-co-hydroxyvalerate (PHBV) mixed with natural rubber latex. In Proceedings of the 8th International Conference on Materials Science and Technology, MSAT 2014, Bangkok, Thailand, 15-16 December 2014; pp. 404-408.

45. Van De Velde, K.; Kiekens, P. Thermal degradation of flax: The determination of kinetic parameters with thermogravimetric analysis. J. Appl. Polym. Sci. 2002, 83, 2634-2643. [CrossRef]

46. Chan, C.H.; Sulaiman, S.F.; Kammer, H.W.; Sim, L.H.; Harun, M.K. Thermal Properties of Epoxidized Natural Rubber-Based Polymer Blends. J. Appl. Polym. Sci. 2011, 120, 1774-1781. [CrossRef]

47. Evstatiev, M.; Simeonova, S.; Friedrich, K.; Pei, X.Q.; Formanek, P. MFC-structured biodegradable poly(l-lactide)/poly(butylene adipate-co-terephatalate) blends with improved mechanical and barrier properties. J. Mater. Sci. 2013, 48, 6312-6330. [CrossRef]

48. Ismail, H.; Shaari, S.M.; Othman, N. The effect of chitosan loading on the curing characteristics, mechanical and morphological properties of chitosan-filled natural rubber (NR), epoxidised natural rubber (ENR) and styrene-butadiene rubber (SBR) compounds. Polym. Test. 2011, 30, 784-790. [CrossRef]

49. Pitarresi, G.; Tumino, D.; Mancuso, A. Thermo-mechanical behaviour of flax-fibre reinforced epoxy laminates for industrial applications. Materials 2015, 8, 7371-7388. [CrossRef]

50. Hughes, M.; Carpenter, J.; Hill, C. Deformation and fracture behaviour of flax fibre reinforced thermosetting polymer matrix composites. J. Mater. Sci. 2007, 42, 2499-2511. [CrossRef] 
51. Sun, C.T.; Wanki Jun, A. Compressive strength of unidirectional fiber composites with matrix non-linearity. Compos. Sci. Technol. 1994, 52, 577-587. [CrossRef]

52. Ashby, M.F.; Jones, D.R.H. Engineering Materials; Elsevier Butterworth-Heinemann: Oxford, UK, 2005; Volume 1.

53. Barkoula, N.M.; Garkhail, S.K.; Peijs, T.; Barkoula, N.M.; Garkhail, S.K.; Peijs, T. Biodegradable composites based on flax/polyhydroxybutyrate and its copolymer with hydroxyvalerate. Ind. Crop. Prod. 2010, 31, 34-42. [CrossRef]

(c) (C) 2019 by the authors. Licensee MDPI, Basel, Switzerland. This article is an open access article distributed under the terms and conditions of the Creative Commons Attribution (CC BY) license (http://creativecommons.org/licenses/by/4.0/). 